\title{
Basel IV implementation: a review of the case of the European Union
}

\author{
Mete Feridun \\ Department of Banking and Finance, Eastern Mediterranean University, \\ Famagusta, Cyprus, and \\ Alper Ozün \\ Visiting Scholar, Faculty of Law, University of Oxford, Oxford, United Kingdom
}

\begin{abstract}
Purpose-Introducing radical changes to the methodologies for the determination of capital requirements, the final stage of the Basel III standards, which is referred to as "Basel IV" by the industry, will be a significant challenge for the global banking sector. This article reviews the main components of the new framework, analyses its ongoing implementation in the European Union and discusses its potential impact on banks, putting forward policy recommendations.

Design/methodology/approach - This article uses primary sources such as the publications by the Basel Committee for Banking Supervision and the European Commission. It also reviews the secondary sources, including both academic articles and analyses by various stakeholders. However, this article does not undertake any empirical analysis.

Findings - This article discusses that Basel IV will introduce strategic, operational and regulatory challenges for banks in scope. It also identifies a number of areas which are subject to further debate in the European Union such as the enhanced due diligence requirements under the new credit risk framework; governance, reporting and control rules under the operational risk framework; exemptions for certain derivative transactions under the credit valuation adjustment framework and the level of application of the capital floors within banking groups. This article concludes that the global implementation of the reforms by all jurisdictions and transposition into national banking laws concurrently with the European Union in line with the Basel Committee's implementation timeline is important from a financial stability standpoint.

Originality/value - The article presents an up-to-date and comprehensive review of the practical implications of Basel IV standards. It analyses the implementation of the standards in the case of the European Union, reviews the potential policy implications and presents recommendations for risk management practitioners.
\end{abstract}

Keywords Basel IV, Basel III, CRR 2, CRD 5, European Union

Paper type Case study

\section{Introduction}

In response to the global financial crisis, the Basel Committee for Banking Supervision (BCBS) introduced Basel III standards to address shortcomings of the pre-crisis regulatory framework. This new prudential regime provides a regulatory foundation for a resilient and stable banking system by enhancing both the quantity and quality of regulatory capital, with a Capital Conservation Buffer (CCB), an optional Countercyclical Capital Buffer (CCyB) and capital buffers for Global Systemically Important Banks (G-SIBs). It also introduces a nonrisk-based leverage ratio and two new liquidity ratios, Liquidity Coverage Ration (LCR) and

(C) Mete Feridun and Alper Özün. Published in Journal of Capital Markets Studies. Published by Emerald Publishing Limited. This article is published under the Creative Commons Attribution (CC BY 4.0) license. Anyone may reproduce, distribute, translate and create derivative works of this article (for both commercial and non-commercial purposes), subject to full attribution to the original publication and authors. The full terms of this license may be seen at http://creativecommons.org/licences/by/4.0/ legalcode

The authors would like to thank two anonymous referees for their valuable comments and suggestions. Authors would also like to thank their colleagues at University of Cambridge and University of Oxford, where they served as Visiting Faculty during the preparation of this article.

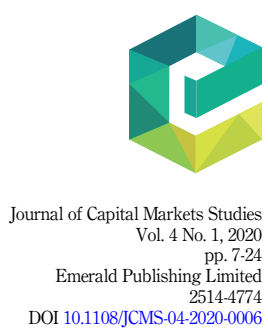


JCMS

4,1

8

Net Stable Funding Ratio (NSFR). While the Basel III framework was originally designed to apply to large, internationally active banks, financial regulators in many jurisdictions across the world have already implemented the main elements of the reforms to a wider set of banks.

However, the BCBS decided to revisit the remaining aspects of the prudential framework in order to reduce excessive variability in risk weighted assets (RWAs) and risk-based capital ratios. This had been necessitated by a number of analyses which had highlighted a worrying degree of variability in banks' calculation of their RWAs, which had resulted in a loss of confidence in their reported regulatory capital ratios. This final stage of the Basel III framework, which is referred to as "Basel IV" by the industry, was published by the BCBS in December 2017. Basel IV comprises measures that aim at enhancing the robustness and risk sensitivity of the standardised approaches (SA) for credit risk and operational risk. In addition, it constrains the use of internal ratings-based (IRB) approaches to credit risk, removes the use of internal modelling approaches to operational risks from the calculation of regulatory capital requirements and overhauls standards with respect to credit valuation adjustment (CVA).

These reforms are expected to facilitate the comparability of banks' capital ratios. These revised standards are complemented by a finalised leverage ratio for G-SIBs and a revised capital floor of $72.5 \%$ to limit the extent to which banks can drive down capital requirements using their internal risk models (BCBS, 2017a, b). Basel IV has been complemented by the revised market risk standard known as the Fundamental Review of the Trading Book (FRTB) [1] and the updated Pillar 3 disclosure requirements [2], both of which are beyond the scope of this article.

So far, legislative progress towards the implementation of Basel IV across different jurisdictions is moving slower than anticipated, with the European Union (EU) being an exception where those standards are being implemented through the revised Capital Requirements Regulation (CRR 2) and Directive (CRD 5) [3]. This is partially driven by the European Banking Authority's (EBA) reports, recommending the full implementation of the final Basel III framework in the EU in response to the European Commission's (EC) call for technical advice in May 2018 (EBA, 2019b).

The BCBS members have already expressed a firm commitment to full, timely and consistent implementation of Basel IV. However, in the case of other jurisdictions, it is not known if the rules would be transposed into the national laws at all. However, due to the lack of adequate public information from the respective national regulators on their implementation efforts, their progress remains uncertain. Basel IV reforms initially had an implementation date of 1 January 2022 onwards. However, to alleviate the impact of coronavirus disease 2019 (COVID-19) on the global banking system, BCBS set out measures in April 2020, postponing the implementation timeline of the outstanding Basel IV standards for one year to 1 January 2023. It also deferred the transitional arrangements for the capital output floor to 1 January 2028 (BCBS, 2020a, b). Table 1 shows the revised implementation timeline and also summarises the intended revisions under Basel IV.

It is against this backdrop that the present article reviews the key Basel IV standards and analyses their ongoing implementation in the EU. This article makes three main contributions to the literature on financial regulations: firstly, it provides a comprehensive and up-to-date review of theoretical and practical implications of Basel IV in the context of banking risk management principles. Secondly, it undertakes an in-depth examination of the implementation of Basel IV in the case of the EU. Finally, it provides policy implications for policymakers and practitioners.

The rest of the article is structured as follows: the next section will discuss the key components of Basel IV. Section 3 will present the conceptual framework with respect to the potential capital impact of Basel IV, whereas Section 4 will review the implementation of Basel IV in the EU. Finally, the last section will highlight the conclusions and policy implications that emerge from this article. 


\begin{tabular}{|c|c|c|c|}
\hline Standard & Original implementation date & Revised implementation date & \\
\hline $\begin{array}{l}\text { Revised leverage ratio } \\
\text { framework and G-SIB buffer }\end{array}$ & 1 January 2022 & 1 January 2023 & \\
\hline $\begin{array}{l}\text { Revised standard approach for } \\
\text { credit risk }\end{array}$ & 1 January 2022 & 1 January 2023 & \\
\hline $\begin{array}{l}\text { Revised internal rating-based } \\
\text { approach for credit risk }\end{array}$ & 1 January 2022 & 1 January 2023 & \\
\hline $\begin{array}{l}\text { Revised operational risk } \\
\text { framework }\end{array}$ & 1 January 2022 & 1 January 2023 & \\
\hline $\begin{array}{l}\text { Revised credit valuation } \\
\text { adjustment framework }\end{array}$ & 1 January 2022 & 1 January 2023 & \\
\hline Output floor & $\begin{array}{l}1 \text { January 2022; transitional } \\
\text { arrangements to } 1 \text { January } 2027\end{array}$ & $\begin{array}{l}1 \text { January } 2023 \text {; transitional } \\
\text { arrangements to } 1 \text { January } 2027\end{array}$ & \\
\hline \multicolumn{3}{|c|}{$\begin{array}{l}\text { Source(s): BCBS, Governors and Heads of Supervision announce deferral of Basel III implementation to } \\
\text { increase operational capacity of banks and supervisors to respond to Covid-19,27 March 2020, https://www.bis. } \\
\text { org/press/p200327.htm }\end{array}$} & $\begin{array}{r}\text { Revised Basel IV } \\
\text { implementation } \\
\text { timeline }\end{array}$ \\
\hline
\end{tabular}

\section{The key components of Basel IV and their implications}

Basel IV fundamentally amends capital calculations across all risk types. Firstly, it limits the use of the Advanced IRB (A-IRB) approach to credit risks for low-default portfolios. Secondly, it removes the internally modelled approach and introduces a revised standardised approach to CVA risks. Thirdly, it revises the SA approach for operational risk and removes the advanced measurement approaches (AMA). Fourthly, it introduces an aggregate output floor to ensure that banks' RWAs generated by internal models are no lower than $72.5 \%$ of RWAs as calculated by the SA approaches. Fifthly, it introduces a leverage ratio buffer for G-SIBs, which will take the form of a Tier 1 capital buffer set at $50 \%$ of a G-SIB's risk-weighted capital buffer (BCBS, 2017a, b).

The implementation of Basel IV will complete the global reform of the regulatory framework, which began in the wake of the financial crisis. It represents one of the biggest challenges for financial institutions in the coming years, with the capital impact for some banks expected to be material even though the BCBS have clarified that that Basel IV revisions are not intended to lead to a significant increase in overall capital requirements at an aggregated industry level. In particular, global banking groups are expected to face significantly higher minimum capital requirements as a result of the full implementation of Basel IV standards (EBA, 2018).

Implementation of Basel IV will have important implications for banks. Firstly, it will require them to consider whether to apply for supervisory approval to use the internal modelling approaches and whether to adjust their business models, strategies and asset portfolios in response to changes in risk weights. Secondly, it will require them to consider whether to meet their regulatory capital ratios through issuing new capital, retained earnings or a reduction in RWAs. This will be particularly challenging during a period when interest rates are at historically low levels across the world and return on equity is likely to remain low particularly amidst the COVID-19 pandemic (Feridun, 2020a).

\subsection{Revised credit risk framework}

Given credit risk is the main driver of most banks' RWAs, changes to the Basel II credit risk framework will represent the biggest challenge for the global banking sector. Basel II allows banks either to use the SA or the IRB approaches to calculate their credit risk capital requirements, which has resulted in risk weights ending up incomparable across banks 
JCMS 4,1

(BCBS, 2004). Hence, as part of the Basel IV reform package BCBS overhauled the credit risk SA approach, improving its granularity and risk sensitivity. It also revised, by and large, all exposure classes to reduce excessive variability in RWAs and improve the comparability of banks' risk-based capital ratios. The final SA approach to credit risk allows banks to use external ratings, where available and permitted by national supervisors, for exposures to banks and corporates. It also allows the use of loan and to improve loan-to-value ratios (LTV) to determine risk weights for retail and commercial real estate exposures.

However, aiming to improve the granularity and risk sensitivity, as well as reducing the mechanistic reliance on credit ratings, BCBS introduced a relatively more granular approach for unrated exposures to banks and corporates, recalibrated risk weights for rated exposures; and introduced separate treatments for covered bonds, specialised lending (SL) [4] and exposures to small and medium-sized enterprises (SMEs) (BCBS, 2017a, b).

While the revised SA approach to credit risk recalibrates risk weights in most asset classes and leads to a significant impact on capital requirements and business models, the final standards are not as detrimental as banks had anticipated in the beginning. This is because the final SA approach applies lower risk weights to higher quality credit exposures than the consultation paper had initially proposed. Generally speaking, the impact of Basel IV on banks' credit risk capital requirements will depend on the composition and quality of their respective loan portfolios. For instance, banks with predominantly high LTV residential and commercial property loans and income-producing real estate (IPRE) will see a significant increase in their capital requirements.

In the case of the mortgage class, for instance, BCBS set out a more risk-sensitive approach based on a LTV ratio, recognising that exposures are materially dependent on cash flow generated by the property. It allows banks to use one of the two alternative approaches, namely the loan splitting (LS) approach and the whole loan (WL) approach. The former separates mortgage loans into a secured and an unsecured part, applying a different risk weights to each. The latter assigns one risk weights to the whole exposure based on different LTV buckets [5]. The LS approach also applies to commercial real estate and its application is subject to the discretion of the national supervisor. In the case of residential exposures not dependent on cash flows, the risk weight varies between 20 and $70 \%$, and between 30 and $105 \%$, where there is a dependency on cash flows. The risk weight is applied to the portion of the exposure that is below $55 \%$ of the property value and the risk weight of the counterparty is applied to the remainder of the exposure.

In particular, Basel IV provides a much greater degree of sensitivity in the case of residential mortgages where Basel II uses a risk weight of $35 \%$ for secure mortgages [6]. It introduces new risk weights ranging between 20 and 105\% depending on whether the mortgage is classified as general residential or IPRE, i.e. buy-to-let. In the case of commercial real estate, the applicable risk weight varies between 60 and $150 \%$ depending on the LTV, in a relatively less granular way than in the residential real estate. In the case of the latter, respective risk weight buckets have become more granular based on the LTV ratio and depending on whether the exposure is to IPRE or general residential real estate. For instance, it set a weight of $70 \%$ for IPRE where LTV is below $60 \%, 90 \%$ if LTV is between 60 and $80 \%$, and $110 \%$ where LTV is above $80 \%$.

In addition, Basel IV introduces operational challenges and complexities, for example by requiring documentation showing the borrower's ability to repay the loan as well as with respect to the valuation of the real estate. In the case of IPRE, it requires banks to undertake an assessment of the cash flows generated by the respective individual property in relation to all other cash flows of the borrower. Basel IV also allows banks to treat loans to individuals that are secured by residential property which is under construction, as real estate exposures as long as the property is a primary family residence of the borrower or if there is a legal guarantee ensuring that the property under construction will be finished. 
As can be seen in Table 2, in the case of exposure to corporates, the BCBS introduces a more granular risk weights for SMEs, whereas, it distinguishes between general corporates and SL in the case of exposures to non-SME corporates. The risk weight ranges from 20 to $150 \%$ depending on external ratings. In the case of jurisdictions that do not permit ratings or for unrated exposures, the risk weights range from 65 to $100 \%$ depending on the risk categories. Under this approach a flat risk weight of $100 \%$ is applicable to all corporate exposures, with the exception of, exposures to corporate SMEs and to investment grade corporates, which are assigned 85 and 65\% risk weights, respectively $(\mathrm{EC}, 2019)$. In the case the External Credit Risk Assessment Approach (ECRA), on the other hand, exposures to rated corporates are assigned a risk weight ranging from 20 to $150 \%$ depending on the credit quality. Exposures to unrated corporates are to be risk-weighted at $100 \%$, unless they qualify as SMEs, in which case they are subject to an $85 \%$ risk weight.

In jurisdictions that allow the use of external ratings, banks are allowed to determine the risk weights in the SA approach using external credit ratings of institutions that are recognised as eligible for capital purposes by national supervisors. However, to prevent mechanistic reliance on external credit ratings and to ensure the risk weight applied is appropriate, BCBS introduced highly demanding due diligence requirements for corporate and bank exposures where ratings are used, with the exception for exposures to sovereigns and public sector entities (EC, 2019). The BCBS expects the sophistication of the due diligence to be appropriate to the size and complexity of banks' activities. For exposures to sovereigns, public sector entities, multilateral development banks, institutions, covered bonds and corporates, the BCBS decided to retain the use of external ratings with alternative approaches available in the case of the unrated exposures to institutions. For exposures to central governments and central banks, the BCBS left risk weightings subject to a further consultation.

In the case of exposures to banks, risk weights range between 20 and $150 \%$ based on external ratings as can be seen in Table 3. In jurisdictions that do not permit ratings or for unrated exposures, the risk weights range from $20 \%$ to $150 \%$ depending on newly defined risk categories under Basel IV. The BCBS introduced the ECRA for banks in jurisdictions that allow the use of external ratings and the Standardised Credit Risk Assessment Approach (SCRA) for all exposures of banks incorporated in jurisdictions that do not allow the use of external ratings. SCRA is more granular than the procedure in Basel II as it classifies all exposures to unrated institutions into one of three grades based on certain quantitative and qualitative criteria.

\begin{tabular}{|c|c|c|c|}
\hline Credit rating score & Risk weights & & \\
\hline \multicolumn{4}{|l|}{ Where credit rating is permitted } \\
\hline Between AAA and AA- & $20 \%$ & & \\
\hline Between A+ and A- & $50 \%$ & & \\
\hline Between BBB+ and BBB- & $75 \%$ & & \\
\hline Between BB+ and B- & $100 \%$ & & \\
\hline Below B- & $150 \%$ & & \\
\hline \multicolumn{4}{|c|}{ Where credit rating is not permitted } \\
\hline General corporate (non-SME) & $65 \%$ & $100 \%$ & \\
\hline SME & $85 \%$ & $85 \%$ & Basel IV risk weights \\
\hline \multicolumn{4}{|c|}{$\begin{array}{l}\text { Source(s): BCBS, High-level summary of Basel III reforms, December 2017, https://www.bis.org/bcbs/publ/ } \\
\text { d424_hlsummary.pdf }\end{array}$} \\
\hline
\end{tabular}




\section{JCMS}

4,1

12
Credit rating score

Where credit rating is permitted

Between AAA and AA-

Between $\mathrm{A}+$ and $\mathrm{A}$ -

Between $\mathrm{BBB}+$ and BBB-

Between $\mathrm{BB}+$ and $\mathrm{B}$ -

Below B-

Where credit rating is not permitted

SCRA class

Class A

Class B

Class C
Long-term

Short-term

Table 3.

$150 \%$
$20 \%$

$20 \%$

$20 \%$

$50 \%$

$150 \%$

Long-term

$40 \%$

$75 \%$

$150 \%$
Short-term

$20 \%$

$50 \%$

$150 \%$

Basel IV risk weights for banks

In the case of subordinated debt and equity, the respective risk weights are categorised based on exposure type and vary between 100 and $400 \%$. As can be seen Table 4, the BCBS developed more granular risk weights for subordinated debt and equity exposures to range from $150 \%$ for subordinated debt and capital other than equities to $250 \%$ for equity exposures other than equity exposures to certain legislated programmes and speculative unlisted equity. The BCBS also provided clarification with respect to the scope of the equity exposure class, specifying which instruments banks should categorise into this category, and introduced risk weights over a five-year transition period from 100 to $250 \%$.

Besides, the BCBS recalibrated credit conversion factors (CCFs) for off-balance-sheet items to range from 10\% for Unconditionally Cancellable Commitments (UCCs) to 100\% for direct credit substitutes and other off-balance-sheet exposures as can be seen in Table 5 . Compared to Basel II, CCF includes two additional buckets (10 and 40\%), increasing
Table 4.

Basel IV risk weights for subordinated debt and equity

\begin{tabular}{lc}
\hline Subordinated debt type & Risk weight \\
\hline Subordinated debt and capital other than equities & $150 \%$ \\
Equity exposures to certain legislated programmes & $100 \%$ \\
"Speculative unlisted equity" & $400 \%$ \\
All other equity exposures & $250 \%$
\end{tabular}

Source(s): BCBS, High-level summary of Basel III reforms, December 2017, https://www.bis.org/bcbs/publ/ d424_hlsummary.pdf

\section{Table 5.}

Basel IV credit conversion factors for off-balance-sheet exposures

\section{Exposures}

CCFs

UCCs

Commitments except UCCs

$10 \%$

$\mathrm{NIF}, \mathrm{RUFs}$ and certain contingent items

Short-term self liquidating trade letters of credit

Direct credit substitutes and other exposures

$20 \%$

$100 \%$

Source(s): BCBS, High-level summary of Basel III reforms, December 2017, https://www.bis.org/bcbs/publ/ d424_hlsummary.pdf 
sensitivity in the treatment of off-balance-sheet items. As can be seen other CCFs include $50 \%$ for Note Issuance Facilities (NIFs), Revolving Underwriting Facilities (RUFs) and certain transaction-related contingent items, as well as $20 \%$ CCF for short-term self-liquidating trade letters of credit arising from the movement of goods. There is also a CCF of $100 \%$ for direct credit substitutes and other off-balance-sheet exposures.

As can be seen in Table 6, BCBS also introduced a new standalone treatment for covered bonds with risk weights ranging from 10 to $100 \%$ based on external ratings. In the case of project finance, on the other hand, the corporate weightings will apply where there exist issuespecific ratings and are permitted. Otherwise, the risk weight will depend on the three distinct phases of the project (pre-operational phase, operational phase and "high quality" operational phase), ranging between 80 and $130 \%$.

Given these changes, Basel IV gives banks an opportunity to reduce their credit risk capital requirements by adjusting the composition of their loan portfolios. Banks can optimise their commercial loan portfolios taking into account the new risk weights such as those in the case of SL, where the risk weights vary widely depending on the nature of the loan. Banks may also consider removing high LTV residential mortgages, which have higher interest rates, and maintaining a low LTV portfolio, which generally carry lower interest rates. However, this will require them to carefully evaluate the impact on their net interest income.

\subsection{Constraints on the use of the IRB approach to credit risk}

The capital impact of Basel IV will also depend on whether the bank currently uses the SA approach or the IRB models for its credit risk. This is because the revised standards remove the capital benefits of the use of IRB models. This means that Basel IV will require all banks to review their risk calculations, processes, data and systems, as well as reconsidering whether it would be feasible to apply for IRB approval or to use the SA approach. In particular, BCBS introduced rules on constraining the use of IRB to credit risk to restore credibility in the calculation of banks' RWAs under Pillar 1, as well as to improve comparability in capital ratios (BCBS, 2017a, b). Although BCBS initially proposed to remove the use of the IRB approach completely for a number of portfolios, it subsequently decided not to eliminate it altogether (Alexander, 2015; Pugsley, 2017). Instead, it constrained them

\begin{tabular}{lc}
\hline Credit rating score & Risk weight \\
\hline Risk weights for rated covered bonds & $10 \%$ \\
Between AAA and AA- & $20 \%$ \\
Between A+ and BBB- & $50 \%$ \\
Between BB+ and B- & $150 \%$ \\
Below B- & \\
Risk weights for unrated covered bonds & Risk weight \\
Risk weight of issuing bank & $10 \%$ \\
$20 \%$ & $15 \%$ \\
$30 \%$ & $20 \%$ \\
$40 \%$ & $25 \%$ \\
$50 \%$ & $35 \%$ \\
$75 \%$ & $50 \%$ \\
$100 \%$ & $100 \%$
\end{tabular}

Source(s): BCBS, High-level summary of Basel III reforms, December 2017, https://www.bis.org/bcbs/publ/ d424_hlsummary.pdf

\section{Basel IV implementation}


JCMS

4,1

14

with increased use of the Foundation IRB (F-IRB) approach, which has supervisory prescribed inputs for inputs such as Probability of Default (PD), Exposure at Default (EAD) and Loss Given Default (LGD).

As can be seen in Table 7, the BCBS removed the option to use the A-IRB approach for large corporates and financial institutions, which are not amenable to robust and prudent modelling due to the low number of defaults observed in these asset classes, which makes it practically impossible for banks to model all of the required risk parameters accurately. More precisely, it allows banks to use the F-IRB or the SA approach only in the case of large and mid-sized corporates with consolidated revenues above $€ 500 \mathrm{~m}$. In the case of banks and other financial institutions, it allows the use of F-IRB and SA approaches only. Furthermore, the BCBS removed the option to use IRB models for equities. Regarding SL, the BCBS also retained the use of both A-IRB and F-IRB, despite its initial proposal. The BCBS decided that income producing real estate which receives different treatment under the SA approach should be considered SL under the IRB approach. It also noted that it will review the slotting approach at a later stage (BCBS, 2017a, b).

Besides, as can be seen in Table 8, the BCBS introduced input floors for PD, EAD and LGD to ensure a minimum level of conservativism in model parameters in the case of asset classes where the IRB approaches remain available. For instance, the BCBS decided that the PD should range between 0.05 and $0.10 \%$, depending on retail classes such as Qualifying Retail Revolving Exposure (QRRE) transactors and revolvers. Also, in the case of LGD it decided that input floors should range between 0 and $50 \%$, depending on the type of the exposure and the collateral type. Furthermore, the BCBS removed the requirement for the Basel II 1.06 scaling factor applied to RWAs determined by the IRB approach to credit risk (BCBS, 2017a, b).

\subsection{Operational risk framework}

During the 2007-2008 global financial crisis, capital requirements for operational risk turned out to be insufficient to cover the related losses incurred by some banks. As a result, as part of Basel IV, BCBS introduced a new SA approach to operational risk, replacing the internal model-based AMA approach and the three existing SA approaches with a single risksensitive standardised approach to be used by all banks. Calculation of operational risk capital under the new SA approach is based on a measure of gross income, referred to as the "Business Indicator" (BI) and bank's own internal loss history over 10 years, referred to as the "Internal Loss Multiplier" (ILM). The BCBS reduces the 10 years of high quality annual loss data requirement to five years for banks that transition to the new approach. On the other hand, in the case of the newly established banks whose ILM is greater than 1, supervisors may allow the use less than five years of historical losses should they believe the losses are representative of their operational risk exposure.

\begin{tabular}{|c|c|c|}
\hline Portfolio/exposure & $\begin{array}{l}\text { Basel II: Available } \\
\text { approaches }\end{array}$ & $\begin{array}{l}\text { Basel III: Available } \\
\text { approaches }\end{array}$ \\
\hline $\begin{array}{l}\text { Large and mid-sized corporates (consolidated } \\
\text { revenues }>€ 500 \mathrm{~m} \text { ) }\end{array}$ & A-IRB, F-IRB, SA & F-IRB, SA \\
\hline Banks and other financial institutions & A-IRB, F-IRB, SA & F-IRB, SA \\
\hline Equities & Various IRB approaches & SA \\
\hline Specialised lending & $\begin{array}{l}\text { A-IRB, F-IRB, slotting, } \\
\text { SA }\end{array}$ & $\begin{array}{l}\text { A-IRB, F-IRB, slotting, } \\
\text { SA }\end{array}$ \\
\hline
\end{tabular}

Table 7.

Revised scope of credit risk IRB approaches for asset classes 


\begin{tabular}{|c|c|c|c|c|c|}
\hline & $\mathrm{PD}$ & Unsecured & $\begin{array}{l}\text { LGD } \\
\text { Secured }\end{array}$ & $\mathrm{EAD}$ & $\begin{array}{r}\text { Basel IV } \\
\text { implementation }\end{array}$ \\
\hline Corporate & $0.05 \%$ & $25 \%$ & $\begin{array}{l}\text { Varying by collateral type } \\
\text { (1) } 0 \% \text { financial } \\
\text { (2) } 10 \% \text { receivables } \\
\text { (3) } 10 \% \text { commercial or } \\
\text { residential real } \\
\text { estate } \\
\text { (4) } 15 \% \text { other physical }\end{array}$ & \multirow[t]{5}{*}{$\begin{array}{l}\text { EAD subject to a floor that is the sum of } \\
\text { (i) the on balance sheet exposures, and } \\
\text { (ii) } 50 \% \text { of the off-balance-sheet } \\
\text { exposure using the applicable CCF } \\
\text { under the SA approach }\end{array}$} & 15 \\
\hline $\begin{array}{l}\text { Retail classes } \\
\text { Mortgages }\end{array}$ & $0.05 \%$ & $\mathrm{~N} / \mathrm{A}$ & $5 \%$ & & \\
\hline $\begin{array}{l}\text { QRRE } \\
\text { transactors }\end{array}$ & $0.05 \%$ & $50 \%$ & N/A & & \\
\hline $\begin{array}{l}\text { QRRE } \\
\text { revolvers }\end{array}$ & $0.10 \%$ & $50 \%$ & $\mathrm{~N} / \mathrm{A}$ & & \\
\hline Other retail & $0.05 \%$ & $30 \%$ & $\begin{array}{l}\text { Varying by collateral type } \\
\text { (1) } 0 \% \text { financial } \\
\text { (2) } 10 \% \text { receivables } \\
\text { (3) } 10 \% \text { commercial or } \\
\text { residential real } \\
\text { estate } \\
\text { (4) } 15 \% \text { other physical }\end{array}$ & & Table 8. \\
\hline \multicolumn{5}{|c|}{$\begin{array}{l}\text { Soruce(s): BCBS, High-level summary of Basel III reforms, December 2017, https://www.bis.org/bcbs/publ/ } \\
\text { d424_hlsummary.pdf }\end{array}$} & $\begin{array}{l}\text { values in the revised } \\
\text { IRB framework }\end{array}$ \\
\hline
\end{tabular}

The new SA approach to operational risk is based on the assumption that operational risk increases at an increasing rate with a bank's income and that experiencing greater operational risk losses in the past would indicate a higher likelihood of future operational risk losses. The adoption of the new approach will require banks to identify, collect and store operational loss data, which will be subject to independent review by internal or external audit functions, as well as national supervisors. However, the BCBS allows national regulators to use discretion to exclude certain operational loss events from their loss component if the loss event in question is not representative of the current operational risk profile.

The BCBS requires banks with a BI higher than $€ 1 b n$, which are classified as "Bucket 2 " and "Bucket 3 " banks, to use an institution-specific ILM for calculating their operational risk regulatory capital. On the other hand, in the case of "Bucket 1 " banks whose BI is equal to or below $€ 1 \mathrm{bn}$, calculation of operational risk capital depends only on BIC. Therefore, ILM data does not affect their operational risk capital. However, these banks are allowed to use bankspecific ILM should their loss data collection meet the relevant regulatory preconditions (EC, 2019).

The BCBS also allows national regulators to use discretion to neutralise the ILM for all banks by setting it to 1 . In this case, banks with above-average historical losses will not be subject to higher own funds requirements but banks with a less severe loss history would not receive a capital relief either $(\mathrm{EC}, 2019)$. This means that where an institution-specific ILM is applied, the loss history of a bank has a direct impact on its operational risk capital calculation. Therefore, the main element of the regulatory operational risk capital calculations under Basel IV is the identification and collection of relevant loss events. The BCBS sets the minimum threshold for including a loss event in the data collection and calculation of average annual losses at $€ 20,000$, allowing national regulators to increase this threshold to $€ 100,000$ for "Bucket 2" and "Bucket 3" banks in line with their respective risk profiles (EC, 2019). 
JCMS

4,1

\subsection{Revised CVA framework}

Under the revised CVA framework, the BCBS introduces four different approaches to calculate the capital requirements, allowing banks with different levels of complexity to calculate their CVA capital requirements using the approach most appropriate to their circumstances. However, arguing that CVA risk, which refers to the change in the mark-tomarket value of a bank's exposures to its derivative counterparties, cannot be fully modelled internally by banks, the BCBS removed the use of a fully internally modelled approach and introduced a new, risk sensitive standardised approach referred to as "SA-CVA" as a default methodology. Furthermore, the BCBS improved the risk sensitivity of the CVA framework by taking into account the exposure component of CVA risk and its associated hedges.

Under SA-CVA, risk sensitivity depends on credit spreads and the market risk factors driving the values of derivatives and therefore, exposure. On the other hand, CVA capital requirement is calculated as a sum of the capital requirements for delta and vega risks calculated for the whole CVA portfolio, taking into account all the eligible hedges. In other words, the new regime does not exempt any particular transactions from the calculation of the capital requirement for CVA risk and, therefore, incorporates a wider range of eligible hedges than the existing approaches that recognise only the hedges pertaining to credit spread risk. Therefore, the new regime takes into account the exposure variability due to change in market risk factors as well.

The capital requirements for delta and vega risks, on the other hand, is a sum of capital requirements calculated independently for interest rate, foreign exchange, counterparty credit spread, reference credit spread, equity and commodity risk types. Also, the scope of eligible hedges for counterparty credit spread now includes proxy hedges which do not directly reference the counterparty, and those hedges which are employed to mitigate sensitivities to market risk factors driving changes in price for derivatives and SFTs. As a result, it allows banks to realise the capital benefit from those hedges which have been put in place to reduce exposure to CVA risk. The BCBS requires banks to calculate the own funds requirement for CVA risk for SFTs measured at fair-value for accounting purposes (EC, 2019). Given the CVA risk is sensitive to the same market risk factors as those instruments held in the trading book, the BCBS aligned the new SA-CVA rules to the revised market risk rules, with the CVA capital requirements calculated on a standalone basis. It also extended the scope of the CVA framework to SFTs that are fair valued, leading to an increase in the CVA capital requirement for those banks with sizeable fair value SFT portfolios.

The BCBS also introduced a basic approach (BA-CVA) consisting of two alternatives called "reduced basic CVA approach", which includes only the capital requirements for covered transactions, and a "full basic CVA approach", which captures the CVA capital requirements for covered transactions and CVA capital requirements for eligible hedges. On the other hand, the BCBS provided institutions with smaller derivatives portfolios with a simple alternative to the revised CVA, allowing banks below a materiality threshold of $€ 100 \mathrm{bn}$, relating to the aggregate notional amount of non-centrally cleared derivatives to calculate their CVA capital requirement as $100 \%$ of their counterparty credit risk requirements.

\subsection{Capital output floors}

In response to concerns with respect to the wide variability in RWA arising from banks' internal models, Basel IV introduces an aggregate internal rating model floor to replace the so-called "Basel I floor", constraining the extent to which banks can use their internal risk models to drive down their capital requirements. The Committee initially considered various alternatives for the floor to be set in the range of $60-90 \%$ of RWAs as calculated under the SA approaches. It also considered other options such as the calculation of floors at a more 
granular level (European Parliament, 2017). However, it eventually decided to set a capital output floor of $72.5 \%$ of the own funds requirements derived under the standardised approaches (BCBS 2017).

This means that capital gains from the use of internal risk models will not be allowed to exceed $27.5 \%$ of the requirements calculated using the standardised approaches, which is expected to present a huge challenge for banks using internal modelling approaches. However, the BCBS does not specify the level of application of the capital output floors in terms of the levels of the banking group, e.g. individual, sub-consolidated and consolidated or solely at the highest level of consolidation. National regulators are allowed to apply a "transitory cap" during which RWAs will not be allowed to exceed $25 \%$ of their current levels because of the capital output floors (EC, 2019).

The BCBS allows a five-years transitional period for banks to adopt the new rules. The BCBS's initial decision was to phase in capital floors gradually from 2022 onwards until reaching the final level of $72.5 \%$ in 2027 . However, as mentioned earlier, it subsequently deferred the implementation by one year as part of its COVID-19 measures. Table 9 shows the revised implementation timetable for the capital floors.

\section{Conceptual framework}

In response to the 2007-2008 global financial crisis, the BCBS reviewed the Basel II standards and published Basel III standards to improve the resilience of the global banking system. The final stage of the Basel III, which the industry refers to as Basel IV, complements the first phase of Basel III to restore credibility of the calculation of banks RWAs and enhance the comparability of banks' capital ratios across different approaches, jurisdictions and banks. More specifically, Basel IV is expected to increase the risk-sensitivity and robustness of the SA approaches banks use while calculating their regulatory capital requirements and to improve the comparability of capital ratios of those banks which receive authorisation to use their internal models.

However, the potential quantitative impact of Basel IV in one jurisdiction may differ from that in another. The standards agreed by the BCBS are not directly applicable in member jurisdictions and are required to be transposed into national laws. The BCBS sets only the minimum standards and jurisdictions may elect to implement more conservative requirements and accelerated transitional arrangements. Therefore, quantitative analyses are instrumental to inform decision-making in different jurisdictions as they consider the implementation in their national laws of the revisions to the credit risk, operational risk and CVA risk frameworks, the introduction of a leverage ratio buffer for G-SIBs and the capital output floor under Basel IV.

The academic literature to date has examined various aspects of the Basel III reforms and (Angelini et al., 2011; Allen et al., 2012; Sayah, 2017; Rubio and Yaob, 2019; James and

\begin{tabular}{lcc}
\hline Capital floor & Original date & Revised date \\
\hline $50 \%$ & 1 January 2022 & 1 January 2023 \\
$55 \%$ & 1 January 2023 & 1 January 2024 \\
$60 \%$ & 1 January 2024 & 1 January 2025 \\
$65 \%$ & 1 January 2025 & 1 January 2026 \\
$70 \%$ & 1 January 2026 & 1 January 2027 \\
$72.5 \%$ & 1 January 2027 & 1 January 2028
\end{tabular}

Source(s): BCBS, Governors and Heads of Supervision announce deferral of Basel III implementation to increase operational capacity of banks and supervisors to respond to Covid-19, 27 March 2020, https://www.bis. org/press/p200327.htm

Table 9. Basel IV revised capital floors 
JCMS

4,1

18

Quaglia 2020). However, there is very limited research on the potential impact of Basel IV due to technical complexity of the subject. In particular, there is a lack of quantitative studies to inform decision-making on the implementation of Basel IV reforms in different jurisdictions. This is mainly because such quantitative assessments will inevitably have to depend on certain unrealistic assumptions such as static balance sheets, which means that banks under study will not alter their exposures and that there are no maturing assets in their portfolios, and that their Pillar 2 capital requirements and $\mathrm{CCyB}$ will remain constant.

Quantitative impact studies will also need to assume that assume that banking regulations will remain unchanged during the implementation of Basel III. However, as shown by the recent policy measures introduced across the world due to the COVID-19 pandemic, these assumptions are not likely to hold in real world (Feridun, 2020b). This makes any quantitative assessments extremely challenging and render their finding subject to controversy.

Nonetheless, in the case of the EU, there exist a number of successive quantitative impact studies conducted by the EBA, the results of which generally show that the impact of the Basel IV package on the capital requirements of globally active banks can be quite significant at the full implementation date. For instance, impact assessment of the Basel IV reform package published by the EBA in October 2018 indicated an expected increase in capital requirements of around $25 \%$ for large and internationally active banks, resulting in significant capital shortfalls (EBA, 2018).

On the other hand, the EBA's Basel III monitoring exercise of October 2019 indicated that once fully implemented, Basel IV standards would lead to an average increase of around $20 \%$ in banks' Tier 1 minimum required capital, driven mostly by the capital output floor and operational risk capital requirement (EBA, 2019a). A subsequent impact study by the EBA in December 2019, which complemented an earlier report published on in August 2019, indicates that the overall impact of Basel IV standards would result in an average increase of around $24 \%$ in the minimum required capital under conservative assumptions.

As shown in Table 10, this assessment, which was based on a sample of 189 banks from 19 EU countries, indicates an aggregate shortfall of around $€ 125 b n$ in total capital for the EU banks (EBA, 2019b) and represents an increase from the EBA's initial forecasts in December 2017, when Basel IV was finally agreed. However, these findings are subject to change given there is currently an ongoing debate over a number of various EU-specific measures, including those with respect to the enhanced due diligence requirements under the new credit risk framework; governance, reporting and control rules under the operational risk framework; exemptions for certain derivative transactions under the CVA framework; and the level of application of the capital floors within banking groups.

Table 10.

The EBA's assessment of the impact of Basel $\mathrm{IV}$ in the EU

\begin{tabular}{lcccccc}
\hline & $\begin{array}{c}\text { CET1 capital } \\
\text { Revised } \\
\text { ratio }(\%)\end{array}$ & $\begin{array}{c}\text { Shortfall } \\
\text { ratio }(\%)\end{array}$ & $\begin{array}{c}\text { Current } \\
(€ \text { billion })\end{array}$ & $\begin{array}{c}\text { Total capital } \\
\text { ratio }(\%)\end{array}$ & $\begin{array}{c}\text { Revised } \\
\text { ratio }(\%)\end{array}$ & $\begin{array}{c}\text { Shortfall } \\
(€ \text { billion })\end{array}$ \\
\hline All banks & 14.4 & 11.6 & 83.0 & 17.9 & 14.4 & 124.8 \\
Large & 14.2 & 11.4 & 82.9 & 17.8 & 14.3 & 123.8 \\
G-SIBs & 12.7 & 10.1 & 46.8 & 16.2 & 12.8 & 75.3 \\
Medium & 17.3 & 15.2 & 0.1 & 18.9 & 16.6 & 0.9 \\
Small & 17.0 & 16.0 & 0.0 & 18.3 & 17.1 & 0.1
\end{tabular}

Source(s): EBA, Basel III reforms: impact study and key recommendations - macroeconomic assessment, CVA and market risk and corresponding Policy advice on Basel III reforms on CVA and market risk, 4 December 2019, https://eba.europa.eu/file/362841/download?token=050iTyEx 


\section{Implementation of Basel IV in the EU: Progress to date and future considerations}

While most jurisdictions have not started implementing Basel IV yet, with the introduction of the Capital Requirements Directive 5 (CRD 5) and Capital Requirements 2 (CRR 2) in June 2019, the EU has already transposed certain elements of the framework in to the EU law. The final CRD2 and CRD5 framework complements and builds on the existing CRD 4 and CRR regimes, introducing a number of important amendments in a number of key Basel III areas including large exposures, leverage ratio, liquidity, market risk, counterparty credit risk, reporting and disclosure requirements, as well as a structural holding company requirement referred to as the Intermediate EU parent undertaking rule for large third-country G-SIBs (Huez and Feridun, 2019).

The framework also includes a number of other regulations ranging from remuneration standards to environmental, social and governance criteria. Referred to as the EU Banking Package, the framework also includes a leverage ratio buffer for G-SIBs and a revised SA approach for CVA risk, both of which are Basel IV elements. However, as can be seen in Table 11, the EU Banking Package does not include the remaining elements of Basel IV such as the revised capital risk SA approach, capital output floors, CVA requirements and the revised operational risk SA standards, which are likely to have a very significant impact on the EU banking sector (EBA, 2018, 2019).

The implementation of the remaining standards under Basel IV in the EU has been a source of controversy. It is known that when the rules were being drawn up by the BCBS, major elements of Basel IV were subject to fierce debate during negotiations until the last minute by countries such as France and Germany, which were concerned that the reforms would disproportionately hit their own financial institutions. It is therefore not surprising that the remaining elements of the Basel IV framework have not been included in the CRR 2 and CRD 5 package and are still being negotiated in EU. Those remaining elements are expected to be implemented via the forthcoming the Capital Requirements Directive 6 (CRD 6) and Capital Requirements 3 (CRR 3) framework. In addition, the FRTB and the updated Pillar 3 disclosures regime are currently being implemented (Feridun, 2019a, b).

In October 2019, the EC launched a public consultation on the implementation of Basel IV in the EU with respect to the key elements of the framework including revisions to credit and operational risks, the introduction of minimum haircut floors for non-centrally cleared securities financing transactions, amendments to the CVA risk framework and the output floor (EC, 2019). Currently, the implementation timeline for CRD 6 and CRR 3 in the EU remains uncertain. While the final framework is expected to be published around mid-2022, the EC is likely to postpone the implementation of Basel IV in the wake of the COVID-19 outbreak.

\subsection{Implementation of leverage ratio in the $E U$}

In terms of the implementation of the leverage ratio, CRR 2 adopts the Basel framework, setting the Tier 1 capital-based leverage ratio requirement at $3 \%$ for all EU banks. However,

\begin{tabular}{lll}
\hline Area & Progress & Remaining areas \\
\hline Leverage ratio & Banking Package & Extension of leverage ratio buffers to O-SIIs \\
Credit risk & In progress & Enhanced due diligence requirements, Sl., CCFs \\
Operational risk & In progress & EU-specific governance, reporting and control rules \\
CVA & Banking Package & Exemptions for certain derivative transactions \\
Output floor & In progress & Level of application within banking groups
\end{tabular}

Source(s): Authors

\section{Basel IV implementation}


JCMS

4,1

CRR 2 leverage ratio rules exclude certain EU-specific items from the exposure measure, such as exposures arising from assets that constitute claims on central governments, regional governments and local authorities where the firm is a public development credit institution. CRR 2 also excludes parts of exposures arising from passing-through promotional loans to other credit institutions, where the firm is not a public development credit institution. CRR 2 leverage ratio also excludes guaranteed parts of exposures that arise from officially supported export credits, where the guarantees are provided by export credit agencies or central governments, provided that a $0 \%$ risk weight is applied to the guaranteed part of the exposure.

Other excluded items under CRR 2 leverage ratio include securitised exposures from traditional securitisations that meet the conditions for significant risk transfer, trade exposure of credit derivatives and SFTs if the institution is a member of a qualifying Central Counterparty (CCP) under the European Market Infrastructure Regulation (EMIR) and meet certain conditions set out in Article 306 of the CRR (BCBS, 2017a, b). In line with the Basel IV framework, the CRR 2 leverage framework adopts an add-on for G-SIBs equal to $50 \%$ of their G-SIB capital buffers, which they should meet by Tier 1 capital. While the leverage ratio buffers will initially apply to G-SIBs only, the EC plans to consider extending it to other systemically important institutions (O-SIIs). The EC is expected to submit a report to the European Parliament and the European Council by 31 December 2020.

\subsection{Implementation of CVA framework in the $E U$}

The implementation of the CVA framework differs from Basel standards. Although Basel IV CVA framework does not exempt any derivative transactions from the calculation of the CVA capital requirement, the current CRR in the EU provides a number of exemptions with respect to derivative transactions with counterparties that were exempted from the clearing and margining requirements under EMIR. These include derivative transactions with counterparties such as certain non-financial, sovereign, intra-group and pension funds. The purpose is to prevent a potentially excessive increase in the cost of derivative transactions. Removal of these exemptions is currently subject to debate in the EU.

There are also ongoing discussions in some other areas with respect to the CVA risks. For instance, some stakeholders argue that the Basel IV CVA framework would discourage the use of more sophisticated and proactive risk management approaches. They also caution that the SA approach to CVA could lead to higher capital requirements than in a situation where no hedging is applied at all (EBF, 2019).

\subsection{Implementation of capital floors in the $E U$}

Regarding capital floors, some stakeholders in the EU argue that the banking sector is responsible for the large majority of lending to businesses and individuals across the EU and the requirement to hold higher capital levels through capital floors could have negative consequences for the supply and pricing of bank finance. Others argue that the lack of risksensitivity of the output floor will be damaging to banks with lower risk profile and create disincentives for the lowest risk portfolios and for exposures with safe risk mitigation tools such as covered bonds. They caution that this may result in the segments of clients of the highest credit quality seeing their cost of credit increase.

Currently, there are ongoing discussions in the EU as to whether the output floor should be applied at all levels of the banking group, i.e. individual, sub-consolidated and consolidated, or at the highest level of consolidation. Other discussions relate to the implementation of the transitional measures, i.e. the transitory to temporarily prevent RWA increase exceeding $25 \%$ in the $\mathrm{EU}(\mathrm{EC}, 2019)$. 

firms" and "investments in private equity" as high risk exposures. Therefore, these items are subject to a risk weight of $150 \%$. These items have been defined under the EBA's guidelines which cover specifications for the types of exposures to be associated with high risk [7].

There is currently an ongoing discussion regarding the risk weights of these exposures and the definition of speculative unlisted equity exposures in the EU. There are also ongoing discussions with respect to the revised credit risk framework such as the enhanced due diligence requirements under the SA approach and the related quantitative and qualitative criteria for the classification of counterparties into grades. Other topics being negotiated regarding the credit risk framework include the specific treatment of SL and the new CCFs within the off-balance-sheet framework (EC, 2019).

\subsection{Implementation of the operational risk framework in the $E U$}

In terms of the implementation of the operational risk framework, the EU already has certain regulations which differ from the Basel II standards. For instance, CRR Articles 320 and 321 include a number of requirements with respect to governance, reporting and control of operational risk, which differ from the Basel standards. These additional EU-specific requirements aim to achieve higher standards of operational risk management than required by the BCBS in its SA approach to operational risk.

The Commission Delegated Regulation 959/2018 also includes certain provisions with respect to the collection of the loss data. These include stringent requirements regarding the processes and procedures for loss data collection, as well as the quality and type of the loss dataset. More specifically, banks are required to have an independent operational risk management function, a well-documented assessment and management processes for operational risk and systems for regular monitoring and reporting of operational risk exposures and losses.

The Commission Delegated Regulation 959/2018 also requires banks to subject their operational risk frameworks to internal or external auditor reviews. Currently, there are ongoing discussions with respect to the continuation of EU-specific regulations under the forthcoming CRR III (EC, 2019).

\section{Conclusion and policy implications}

This article has reviewed the Basel IV standards which complement Basel III reforms by improving the robustness and risk sensitivity of the SA approaches for credit risk, CVA risk and operational risk; removing the use of the internal modelling approaches for CVA risk and for operational risk; placing parameter input floors under the IRB approach for credit risk; imposing a leverage ratio buffer on G-SIBs and introducing a capital floor based on the revised SA approaches. As discussed earlier, these measures are expected to restore credibility in the calculation of RWAs and improve the comparability of banks' capital ratios.

The article also analysed its implementation of Basel IV in the EU, reviewing the progress so far and discussing the remaining elements which are currently being negotiated. The article makes a contribution to the ongoing debate on benefits, challenges and implications of Basel IV by highlighting a number of EU-specific measures which are subject to debate. These include the enhanced due diligence requirements under the new credit risk framework; governance, reporting and control rules under the operational risk framework; exemptions for certain derivative transactions under the CVA framework and the level of application of the capital floors within banking groups. Based on this review, a number of conclusions 
JCMS 4,1

\section{2}

emerge, which have important implications for policymakers and practitioners in other jurisdictions.

Firstly, as the article emphasised, the EU is the first jurisdiction to start implementation of the Basel IV. From a global standpoint, this makes it important for all jurisdictions to mirror the EU-level adoption of certain rules as much as possible to ensure consistency in cross-border banking regulations. Given the fundamental changes and the associated implementation challenges posed by Basel IV, its consistent implementation across all jurisdictions is crucial to avoid pricing distortions and an unlevel playing field across jurisdictions.

Secondly, simultaneous implementation of Basel IV across all jurisdictions is required to avoid regulatory arbitrage opportunities. While the benefits of timely regulatory action to implement Basel IV are indisputable, the Basel standards are not directly applicable by member state regulators and are often subject to lengthy political debate. However, delays in concurrent implementation could put the BCBS's post-crisis efforts to enhance the prudential framework for the global banking sector in jeopardy. From a policy standpoint, this requires a concerted effort from all stakeholders and national regulatory authorities.

Thirdly, while the postponement of the implementation date of Basel IV for a duration of 1year and the deferral of the transitional arrangements for the capital output floor to 1 January 2028 due to COVID-19 pandemic is welcome and is not expected to dilute the capital strength of the global banking system, this could potentially jeopardize the global implementation of the standards, affecting the motivation of the national regulators to transpose it into their respective domestic regulations. From a financial stability standpoint, it is imperative that all national authorities remain aligned with BCBS's implementation timeline.

Finally, the introduction of Basel IV standards pertaining to the calculation of riskweighted assets and thus to the capital ratios of all banks will have fundamental repercussions on banks' strategies, business models and operations. This will require the industry to make a significant investment in technology, risk modelling and new staff members, with a subsequent increase in compliance costs. Postponement of the implementation of Basel IV should not delay banks' preparations. They should carefully explore the potential balance sheet and business model impacts along with any other broader implications, and consider mitigating management actions.

Directions for future studies: We recommend that future studies measure the potential impact of Basel IV implementation in non-EU countries using quantitative methodologies to inform decision-making on the implementation of the reforms in the respective jurisdictions. On the other hand, studies focussing on the EU implementation of Basel IV are recommended to focus on the assessment of the advantages and disadvantages of various EU-specific measures with respect to the enhanced due diligence requirements under the new credit risk framework; governance, reporting and control rules under the operational risk framework; exemptions for certain derivative transactions under the CVA framework and the level of application of the capital floors within banking groups.

\section{Notes}

1. See "Basel III: Finalising post-crisis reforms", available at: https://www.bis.org/bcbs/publ/d424.pdf.

2. See "Pillar 3 disclosure requirements - updated framework", available at: https:/www.bis.org/bcbs/ publ/d455.pdf

3. See https://europa.eu/rapid/press-release_MEMO-19-2129_en.pdf.

4. SL comprises project finance, object finance and commodities finance.

5. The LS approach applies the risk weight of the counterparty to the unsecured part of the loan and reflects the risk mitigating effects of the collateral. 
6. Under Basel II any unsecured component of residential mortgages carries a higher risk weight than $35 \%$ (See BCBS, 2004).

7. See https://eba.europa.eu/regulation-and-policy/credit-risk/guidelines-on-specification-of-typesof-exposures-tobe-associated-with-high-risk

\section{References}

Alexander, P. (2015), Europe to Reconsider Banks' Internal Models, available at: https://www. globalriskregulator.com/Subjects/Capital/Europe-to-reconsider-banks-internal-models (accessed 10 March 2015).

Allen, B., Chan, K., Milne, A. and Thomas, S. (2012), "Basel III: is the cure worse than the disease?", International Review of Financial Analysis, Vol. 25, pp. 159-166.

Angelini, P., Clerc, L., Cúrdia, V., Gambacorta, L., Gerali, A., Locarno, A., Motto, R., Roeger, W., Van den Heuvel, S. and Vlček, J. (2011), "Basel III: long-term impact on economic performance and fluctuations", BIS Working Papers, Vol. 338, available at: https://www.bis.org/publ/ work338.pdf.

BCBS (2004), "International convergence of capital measurement and capital standards - a revised framework comprehensive version", available at: https://www.bis.org/publ/bcbs128.pdf.

BCBS (2017a), Basel III: Finalising Post-crisis Reforms, December 2017, available at: https://www.bis. org/bcbs/publ/d424.pdf.

BCBS (2017b), High-level Summary of Basel III Reforms, December 2017, available at: https://www.bis. org/bcbs/publ/d424_hlsummary.pdf.

BCBS (2020a), Governors and Heads of Supervision Announce Deferral of Basel III Implementation to Increase Operational Capacity of Banks and Supervisors to Respond to Covid-19, Press release, available at: https://www.bis.org/press/p200327.htm (accessed 27 March 2020).

BCBS (2020b), Basel Committee Sets Out Additional Measures to Alleviate the Impact of Covid-19, Press release, available at: //www.bis.org/press/p200403.htm (accessed 3 April 2020).

EBA (2018), Basel III Monitoring Exercise - Results Based on Data as of 31 December 2017, available at: https:/eba.europa.eu/sites/default/documents/files/documents/10180/2380948/e2e09646-2594 -48a5-b794-a7c2348257db/2018 Basel III Monitoring ExerciseReport.pdf?retry=1 (accessed 4 October 2018).

EBA (2019a), Basel III Monitoring Exercise —Results Based on Data AS of 31 December 2018, October 2019, available at: https:/eba.europa.eu/sites/default/documents/files/documents/10180/2551 996/4686802a-94b7-474e-b937-adaa4e6faa26/Basel III monitoring exercise.pdf?retry=1.

EBA (2019b), Basel III Reforms: Impact Study and Key Recommendations - Macroeconomic Assessment, CVA and Market Risk and Corresponding Policy Advice on Basel III Reforms on CVA and Market Risk, available at: https://eba.europa.eu/file/362841/download?token=050i TyEx (accessed 4 December 2019).

EBF (2019), EBF Summary on Basel IV1 in Europe, available at: https://www.ebf.eu/wp-content/ uploads/2019/06/EBF_033787-EBF-summary-paper-on-Basel-IV-in-Europe-final-updated-clean. pdf (accessed 26 March 2019).

European Parliament (2017), "Upgrading the Basel standards: from Basel III to Basel IV?", available at: https://www.europarl.europa.eu/RegData/etudes/BRIE/2016/587361/IPOL_BRI (2016)587361_EN.pdf.

EC (2019), Public Consultation Document Implementing the Final Basel III Reforms in the EU, available at: https:/ec.europa.eu/info/sites/info/files/business_economy_euro/banking_and_ finance/documents/2019-basel-3-consultation-document_en.pdf (accessed 11 October 2019).

Feridun, M. (2019a), Integration of Pillar 3 Disclosures into Regulatory Reporting: New Challenges and Opportunities, Finextra, available at: https://www.finextra.com/blogposting/18385/integration- 
JCMS

4,1

of-pillar-3-disclosures-into-regulatory-reporting-new-challenges-and-opportunities (accessed 12 February 2020).

Feridun, M. (2019b), Inconsistent Implementation of the FRTB Could Jeopardize Post-Crisis Banking Reforms, Duke Law Global Financial Markets Center FinReg Blog, available at: https://sites. duke.edu/thefinregblog/2019/11/20/inconsistent-implementation-of-the-frtb-could-jeopardize-post -crisis-banking-reforms (accessed 20 November 2019).

Feridun, M. (2020a), COVID-19 Outbreak Requires Prompt and Innovative Regulatory Response, Duke Law Global Financial Markets Center FinReg Blog, available at: https://sites.duke.edu/ thefinregblog/2020/04/07/covid-19-outbreak-requires-prompt-and-innovative-regulatory-response/ (accessed 7 April 2020).

Feridun, M. (2020b), COVID-19 Should Not Jeopardize the Implementation of Basel IV, Duke Law Global Financial Markets Center FinReg Blog, available at: https://sites.duke.edu/thefinregblog/2020/04/ 23/covid-19-should-not-jeopardize-the-implementation-of-basel-iv (accessed 23 April 2020).

Huez, H. and Feridun, M. (2019), CRR II and CRD V Are Finally Here: What Should Firms Expect?, PwC Being Better Informed, July 2019, available at: https://www.pwc.co.uk/financial-services/ assets/pdf/being-better-informed-july-2019.pdf.

James, S. and Quanglia, L. (2020), The UK and Multi-Level Financial Regulation: From Post-crisis Reform to Brexit, Oxford University Press, Oxford, UK.

Pugsley, J. (2017), ECB Aims to Raise Credibility of Internal Models, Global Risk Regulator, 24 March, available at: https://www.globalriskregulator.com/Subjects/Capital/ECB-aims-to-raise-credib ility-of-internal-models?ct=true.

Rubio, M. and Yaob, F. (2020), "Bank capital, financial stability and Basel regulation in a low interestrate environment”, International Review of Economics and Finance, Vol. 67, pp. 378-392.

Sayah, M. (2017), "Counterparty credit risk in OTC derivatives under Basel III", Journal of Mathematical Finance, Vol. 7, pp. 1-38, doi: 10.4236/jmf.2017.71001.

\section{Corresponding author}

Mete Feridun can be contacted at: mete.feridun@emu.edu.tr

For instructions on how to order reprints of this article, please visit our website:

www.emeraldgrouppublishing.com/licensing/reprints.htm

Or contact us for further details: permissions@emeraldinsight.com 